\begin{tabular}{|l|l|l||}
\hline \multicolumn{2}{|c|}{ PublisherInfo } \\
\hline \hline PublisherName & $:$ & BioMed Central \\
\hline \hline PublisherLocation & $:$ & London \\
\hline \hline PublisherImprintName & $:$ & BioMed Central \\
\hline \hline
\end{tabular}

\title{
Polycomb in the prostate
}

\begin{tabular}{|l|l|l||}
\hline \multicolumn{2}{|c||}{ ArticleInfo } \\
\hline \hline ArticleID & $:$ & 4612 \\
\hline \hline ArticleDOI & $:$ & $10.1186 /$ gb-spotlight-20021017-01 \\
\hline \hline ArticleCitationID & $:$ & spotlight-20021017-01 \\
\hline \hline ArticleSequenceNumber & $:$ & 278 \\
\hline \hline ArticleCategory & $:$ & Research news \\
\hline ArticleFirstPage & $:$ & 1 \\
\hline \hline ArticleLastPage & $:$ & 2 \\
\hline \hline & $:$ & RegistrationDate : 2002-10-17 \\
ArticleHistory & $:$ & OnlineDate \\
\hline \hline ArticleCopyright & $:$ & BioMed Central Ltd2002-10-17 \\
\hline \hline ArticleGrants & $:$ & \\
\hline \hline ArticleContext & $:$ & 130593311 \\
\hline \hline
\end{tabular}




\section{Jonathan B Weitzman}

Email: jonathanweitzman@hotmail.com

Prostate cancer becomes fatal when associated with metastasis. In the October 10 Nature, Varambally et al. describe a microarray-based analysis of genes whose expression is altered in metastatic prostate cancer (Nature 2002, 419:624-629). They identified 55 genes that were upregulated in metastatic tumors relative to localized ones, and found that the gene encoding the polycomb-group protein Enhancer of zeste homolog 2 (EZH2) was significantly upregulated in metastatic cells and correlated with cancer progression. Disruption of EZH2expression by RNAi caused growth inhibition and growth arrest at the G2- to M-phase transition in the cell cycle. Overexpression of EZH2 in cancer cells caused repression of a subset of genes, and this required the EZH2 'SET' domain and endogenous histone deacetylase activity.

\section{References}

1. Delineation of prognostic biomarkers in prostate cancer.

2. Nature, [http://www.nature.com]

3. Polycomb group protein complexes: do different complexes regulate distinct target genes? 